М.В. Пікуль, Е.О. Стаховський, О.А. Войленко, О.Е. Стаховський, Ю.В. Вітрук, О.А. Кононенко, С.Л. Семко, Б.О. Гречко, Д.О. Кошель

\title{
Резекція нирки при уротеліальному раку чашечок високого ступеня ризику
}

\author{
Національний інститут раку, Київ \\ Одержано: 9.10.2020 \\ Прийнято до друку: 10.11.2020 \\ DOI: 10.32471/clinicaloncology.2663-466X.39-3.27391
}

Карциноми верхніх сечових шляхів (КВСШ) становлять близько 10\% випадків новоутворень нирок та $5 \%$ серед уротеліальних пухлин. Вкрай мало виражена клінічна картина досить часто призводить до виявлення патології на пізніх стадіях. Близько 60-80\% випадків на момент встановлення діагнозу характеризуються інвазивним мультифокальним ростом. Радикальна нефроуретеректомія - стандарт лікування КВСШ - призводить до погіршення функції нирок. Втрата функції нирок знижує можливість проведення системної хіміотерапії і погіршує показники виживаності. Анатомічне розміщення уротеліальних утворень у чашечках нирки вважається хірургічно складною локалізацією. Виконання органозберігаючого лікування при інвазивних уротеліальних карциномах у цій точці, згідно з даними літератури, лімітоване окремими клінічними випадками та його віддалені функціональні й онкологічні результати є невивченими. Метою роботи було визначення онкологічної та функціональної ефективності виконання резекції чашечок нирки при інвазивних КВСШ. Матеріали та методи. Після проведення ретроспективного аналізу медичної документації 125 пацієнтів з КВСШ, що підлягали хірургічному лікуванню у відділенні пластичної та реконструктивної онкоурології на базі Національного інституту раку з 2008 до 2020 р., було виділено групу з 10 пацієнтів з пухлинами чашечок нирки високого ризику, у котрих використовували органозберігаючий підхід. Усім обраним хворим проведено комплексне обстеження, що включало комп'ютерну або магнітно-резонансну томографію, цистоскопію з уретероскопією та біопсією новоутворення, цитологічне дослідження сечі та динамічну реносцинтиграфію. Місцево-поширений характер росту пухлини був критерієм виключення з дослідження. Враховуючи невелику вибірку пацієнтів, оцінка клінічних результатів групи проводилася на основі тесту Фішера. Результати. Період спостереження за пацієнтами коливався в межах від 3 до 107 міс та в середньому становив 35 міс. Середній вік хворих - 59 років. У 4 пацієнтів на доопераційному етапі отримано позитивні результати цитологічного дослідження сечі. Розмір пухлини коливався в межах від 2,3 до 6,6 см (у середньому 4,3 см). Середній час оперативного втручання становив 238 36 хв (коливався в межах 186-269). Усі оперативні втручання виконувалися без використання центральної ішемії. Інтраопераційно після мобілізації нирки 3 метою уточнення меж резекції проводилося розсічення ниркової миски, через яку заводився гнучкий уретеропієлоскоп та під візуальним контролем проводилося остаточне планування лінії резекції. Крововтрата в середньому становила 400 мл (коливалася в межах 150-850 мл). Тривалість перебування в стаціонарі в післяопераційний період становила 6,3 11,8 доби (коливалася в межах 3-9 днів). У 4 з 9 пацієнтів в післяопераційний період відмічено ускладнення з медіанним показником за шкалою Clavien - Dindo 1,5 (коливався в межах 1-2). У всіх пацієнтів згідно з даними патоморфологічного дослідження було верифіковано уротеліальну карциному, котра у 1 хворого була високодиференційованою, у 5 - помірно- та у 3 низькодиференційованою. У жодного хворого не було виявлено клінічних даних про рак in situ. Функція ураженої нирки через 1 рік після оперативного втручання в середньому становила 17 мл/хв. Під час аналізу за допомогою точного тесту Фішера не виявлено статистично достовірної залежності між залишковою паренхімою та показниками унілатеральної клубочкової фільтрації $(p=0,173)$ або рівнем післяопераційного креатиніну $(p=0,163)$. У одному $(10 \%)$ випадку відмічено локальний рецидив захворювання, що потребував наступної радикальної нефроуретеректомії та системної терапії у зв'язку з прогресуванням і розвитком метастазів. 3 метою профілактики рецидиву 7 пацієнтам проведено 3 курси ад'ювантної поліхіміотерапії за схемою гемцитабін - цисплатин у стандартних дозуваннях. Відтак у досліджуваній групі лише у 1 (10\%) пацієнта відмічено прогресування на фоні лікування, він помер внаслідок метастазування хвороби. Згідно зі статистичним аналізом за Фішером, ризик локального рецидиву в сечовій системі не залежав від розміру пухлини $(p=0,932)$ або її морфологічної будови $(p=1,0)$. Висновки. Резекція сегменту верхніх сечових шляхів $\epsilon$ перспективним методом хірургічного лікування, що дозволяє зберегти ниркову функцію при ідентичних онкологічних результатах. Збереження функції нирки дозволяє не тільки знизити вірогідність розвитку ниркової недостатності, що позитивно впливає на перебіг супутньої патології, але й залишає можливість проведення ад'ювантної хіміотерапії.

Ключові слова: уротеліальний рак; карцинома верхніх сечовивідних шляхів; радикальна нефроуретеректомія; малоінвазивні органозберігаючі оперативні втручання; клубочкова фільтрація; уротеліальні утворення чашечок нирки; ендоскопічна верифікація діагнозу, метастатична хвороба.

\section{ВСТУП}

Уротеліальний рак є достатньо агресивним захворюванням та в структурі онкологічних хвороб посідає 4-те місце за поширеністю серед чоловічого населення. Карциноми верхніх сечовивідних шляхів (КВСШ) становлять близько $10 \%$ випадків новоутворень нирок та $5 \%$ - серед уротеліальних пухлин $[8,10]$. Вкрай мало виражена клінічна картина досить часто призводить до виявлення патології на пізніх стадіях. Близько 60-80\% випадків на момент встановлення діагнозу характеризуються інвазивним мультифокальним ростом, у 25\% пацієнтів діагностується регіонарне метастазування, у $17-50 \%$ - конкомітантне ураження сечового міхура $[11,12]$.
Незважаючи на розвиток методів обстеження, специфічність анатомо-функціональних змін під час даної нозології, недостатність адекватних стадіювання та селекції призводять до високого рівня нефроуретеректомій у пацієнтів з КВСШ. Затримка виявлення та початку лікування впливає на кінцевий онкологічний результат [1].

Лікування КВСШ різко змінилося протягом останніх двох десятиріч завдяки технічним досягненням та кращому розумінню його патогенезу, що лежить в основі клінічного перебігу цього захворювання [9].

Малоінвазивні органозберігаючі ендоскопічні втручання не показали очікуваних результатів в питаннях підвищення 
безрецидивної та загальної виживаності $[12,15]$. Крім того, ендоскопічні методи мають технічні обмеження та згідно з рекомендаціями Європейської асоціації урологів (European Association of Urology - EAU) можуть бути виконані при пухлинах, менших за 2 см, у разі відсутності низькодиференційованої пухлини за даними цитологічного дослідження сечі та неівазивного росту згідно з даними томографії. Відповідно до клінічних даних при інвазивних та місцево-поширених пухлинах, органозберігаюча тактика зазвичай показана за наявності єдиної нирки або білатеральних ураженнях. Радикальна нефроуретеректомія (РНУЕ) з висіченням іпсилатерального вічка сечоводу залишається золотим стандартом лікування [7, 10, 15].

У пацієнтів з клінічно локалізованими формами КВСШ на момент виконання радикальної нефроуретеректомії досить часто відмічають прогресування хвороби та в подальшому вони помирають від метастазування хвороби [13, 15]. До статистично значущих факторів, що впливають на прогноз захворювання та дозволяють визначити тактику лікування, належать лише стадія та рівень диференціації пухлини $[13,16]$. Достовірність результатів клінічних досліджень обмежена малою вибіркою пацієнтів, що пов'язано з низькою частотою нозології в популяції.

Аналіз даних мультицентрових досліджень довів однакову ефективність впливу на канцер-специфічну виживаність сегментарної резекції ураженої частини сечоводу в порівнянні з РНУЕ [4]. Проте органозбереження у обраної категорії пацієнтів забезпечувало нижчий рівень локального контролю над захворюванням. Клінічні дані продемонстрували високий рівень залежності між нефректомією та розвитком хронічної ниркової недостатності та підвищенням кардіоваскулярних ризиків $[2,3]$. РНУЕ суттєво знижує рівень клубочкової фільтрації, особливо у пацієнтів старшої вікової групи, і як наслідок, лише у $20 \%$ випадків після органовиносних втручань, $є$ вищою за 60 мл/хв, що значно обмежує ймовірність проведення в подальшому хіміотерапії на основі цисплатину [5].

Доведеним фактом є позитивний вплив хіміотерапії на основі цисплатину на результати лікування онкопатології. Так, неоад'ювантна хіміотерапія покращувала виживаність пацієнтів з інвазивним та місцево-поширеними формами КВСШ на $30 \%$. Проведення вказаного лікування на доопераційному етапі було можливим завдяки задовільним показникам функції нирок та обмежувалося у післяопераційний період [11].

Виходячи з вищевикладеного, можна констатувати, що радикальна РНУЕ, стандарт лікування КВСШ, призводить до погіршення функції нирок. Втрата функції нирок знижує можливість проведення системної хіміотерапії і погіршує показники виживаності.

Анатомічне розміщення уротеліальних утворень у чашечках нирки вважається хірургічно складною локалізацією. Виконання органозберігаючого лікування при інвазивних уротеліальних карциномах у цій точці, згідно з даними літератури, обмежене окремими клінічними випадками та його віддалені функціональні і онкологічні результати є невивченими.

Метою роботи було визначення онкологічної та функціональної ефективності виконання резекції чашечок нирки при інвазивних КВСШ.

\section{МАТЕРІАЛИ ТА МЕТОДИ}

Після проведення ретроспективного аналізу медичної документації 125 пацієнтів з КВСШ, яким було проведено хірургічне лікування у відділенні пластичної та реконструктивної онкоурології на базі Національного інституту раку з 2008 до 2020 р., виділено групу з 10 пацієнтів з пухлинами чашечок нирки, що належали до прогностичної групи високого ризику та підлягали органозберігаючому підходу.

Всім обраним хворим проведено комплексне обстеження, що включало комп'ютерну або магнітно-резонансну томографію, цистоскопію з уретероскопією та біопсією ново- утворення, цитологічне дослідження сечі та динамічну реносцинтиграфію. Місцево-поширений характер росту пухлини був критерієм виключення з дослідження.

Оцінка соматичного статусу проводилася на основі коморбідного індексу Чарльсона та ECOG-статусу [14]. Післяопераційні ускладнення характеризувалися з використанням шкали Clavien - Dindo [6]. Онкологічні результати оцінювалися через кожні 3 міс протягом 2 років після хірургічного лікування та обов'язково включали комп'ютерну томографію з екскреторною фазою, цистоскопію та цитологічне дослідження сечі. Оцінка загальної та клубочкової фільтрації унілатеральної нирки проводилася на основі даних динамічної реносцинтиграфії та формули Кокрофта - Голта до оперативного втручання, через 3 та 12 міс після хірургічного лікування. Відсоток залишкової паренхіми нирки визначався перед оперативним втручанням на основі підрахунків згідно з даними комп'ютерної томографії за оригінальною методикою відділу.

Враховуючи невелику вибірку пацієнтів, статистична оцінка клінічних результатів групи проводилася на основі точного тесту Фішера.

\section{РЕЗУЛЬТАТИ}

Період спостереження за пацієнтами коливався в межах від 3 до 107 міс та в середньому становив 35 міс. Середній вік хворих -59 років. Демографічні показники пацієнтів групи підсумовано в табл. 1.

Усі пацієнти підлягали ендоскопічній верифікації діагнозу та визначенню меж ураження на доопераційному етапі. Клініко-морфологічні характеристики пухлин представлені в табл. 1. При уретеро-цистоскопії даних про конкомітантне ураження сечоводу та сечового міхура не отримано у жодного пацієнта. У 4 пацієнтів на доопераційному етапі отримано позитивні результати цитологічного дослідження сечі. Розмір пухлини коливався в межах від 2,3 до 6,6 см (у середньому 4,3 см).

У одному випадку у пацієнта діагностовано двобічні пухлини нирок та двобічний гідронефроз, що потребував корекції у вигляді пластики мисково-сечовідного сегмента. Пацієнту було встановлено двобічні нефростоми та проведено 3 курси неоад'ювантної хіміотерапії на основі гемцитабіну та цисплатину, на фоні чого отримано регресію пухлин з обох боків: зліва 66\% за Критеріями оцінки відповіді солідних пухлин (Response evaluation criteria in solid tumours - RECIST) ( 362 мм до 21 мм), справа $-31 \%$ (з 41мм до 27мм), що дозволило провести успішну двохетапну резекцію нирок.

Середній час оперативного втручання для групи становив $238 \pm 36$ хв (коливався в межах 186-269). Переважна більшість пацієнтів (9 з 10) підлягали оперативному втручанню без використання центральної ішемії. Інтраопераційно після мобілізації нирки з метою уточнення меж резекції проводилося розсічення ниркової миски, через яку заводився гнучкий уретеропієлоскоп та під візуальним контролем проводилося остаточне планування лінії резекції. Крововтрата в середньому становила 400 мл (коливалася в межах 150-850 мл). Тривалість перебування в стаціонарі в післяопераційний період становила $6,3 \pm 1,8$ доби(коливалася в межах 3-9 днів). У 4 з 9 пацієнтів в післяопераційний період відмічено ускладнення з медіанним показником за шкалою Clavien - Dindo 1,5 (коливався в межax 1-2), що були успішно проліковані консервативно. Жоден із хворих не підлягав повторній госпіталізації в 90-денний період після виписки зі стаціонару.

У всіх пацієнтів згідно з даними патоморфологічного дослідження було верифіковано уротеліальну карциному, котра у одного хворого була високодиференційованою $(\mathrm{G} 1)$, у 5 - помірно- (G2) та у 3 - низькодиференційованою (G3). У жодного хворого не було виявлено клінічних даних про рак in situ на візуально неуражених ділянках видаленого сегменту верхніх сечовивідних шляхів. Регіонарна лімфаденектомія не проводилася у жодного хворого, враховуючи відсутність 
збільшених лімфатичних вузлів. У 2 хворих під час оцінки виявлено морфологічні дані, що свідчили про ангіо-лімфатичну інвазію. Клініко-морфологічні дані систематизовано в табл. 2.

Середній відсоток збереженої паренхіми становив $64 \%$. Жоден пацієнт, враховуючи збереження обох нирок, не потребував системного гемодіалізу в післяопераційний період. Функціональні характеристики нирок на боці ураження та клубочкової фільтрації представлені в табл. З. Задовільні показники загальної клубочкової фільтрації дозволили більш широко проводити ад’ювантну хіміотерапію на основі цисплатину у післяопераційний період (див. табл. 3). Функція ураженої нирки через 1 рік після оперативного втручання в середньому становила 17 мл/хв. Варто відмітити, що центральна ішемія на етапі видалення препарату фактично використовувалася лише в 1 випадку, що у тому числі було спрямовано на максимальне збереження пошкодженої функції нирок. Під час аналізу за допомогою точного тесту Фішера не виявлено статистично достовірної залежності між залишковою паренхімою та показниками унілатеральної клубочкової фільтрації $(\mathrm{p}=0,173)$ або рівнем післяопераційного креатиніну $(\mathrm{p}=0,163)$.

Онкологічні результати представлено в табл. 4. У одному (10\%) випадку відмічено локальний рецидив захворювання, що потребував радикальної нефроуретеректомії та системної терапії у зв'язку з прогресуванням захворювання з утворенням метастазів. У 2 випадках під час контрольного обстеження відмічено рецидив захворювання в сечовому міхурі впродовж 6-місячного періоду після основного етапу лікування. Це слугувало причиною для виконання трансуретральної резекції та внутрішньоміхурової хіміотерапії. У подальшому даних про рецидив захворювання у обраних хворих не відмічено. Під час аналізу супутньої патології не виявлено зростання ECOG-статусу та індексу Чарльстона впродовж 1 року спо-

Таблиця 1. Демографічні показники пацієнтів

\begin{tabular}{|c|c|c|c|c|c|c|c|c|c|c|}
\hline \multirow[b]{2}{*}{ Показник } & \multicolumn{10}{|c|}{ Пацієнт } \\
\hline & 1 & 2 & 3 & 4 & 5 & 6 & 7 & 8 & 9 & 10 \\
\hline Вік, років & 59 & 63 & 72 & 57 & 71 & 73 & 39 & 49 & 42 & 64 \\
\hline Стать & Чоловік & Чоловік & Чоловік & Жінка & Чоловік & Чоловік & Чоловік & Чоловік & Жінка & Чоловік \\
\hline Індекс маси тіла & 25,7 & 21,2 & 31,2 & 26,7 & 24,9 & 23,6 & 26,7 & 27,7 & 22,1 & 28,2 \\
\hline Наявність супутніх захворювань: & & & & & & & & & & \\
\hline • цукровий діабет & & & & & Так & Так & & & & \\
\hline - гіпертонічна хвороба & Так & Так & Так & & Так & Так & & & & Так \\
\hline • коронарна патологія & & & Так & & & Так & & & & \\
\hline • тютюнопаління & так & Так & Так & Так & Так & Так & & & & Так \\
\hline • елективні показання до органозбереження & так & Так & Так & Так & Так & & & Так & Так & Так \\
\hline
\end{tabular}

Таблиця 2. Клініко-морфологічні характеристики пухлин

\begin{tabular}{|c|c|c|c|c|c|c|c|c|c|c|}
\hline \multirow{2}{*}{ Показник } & \multicolumn{10}{|c|}{ Пацієнт } \\
\hline & 1 & 2 & 3 & 4 & 5 & 6 & 7 & 8 & 9 & 10 \\
\hline Локалізація пухлини & $\begin{array}{c}\text { Верхні } \\
\text { чашечки }\end{array}$ & $\begin{array}{c}\text { Нижні } \\
\text { чашечки }\end{array}$ & $\begin{array}{l}\text { Нижні } \\
\text { чашечки }\end{array}$ & $\begin{array}{l}\text { Верхні } \\
\text { чашечки }\end{array}$ & $\begin{array}{l}\text { Верхні } \\
\text { чашечки }\end{array}$ & $\begin{array}{l}\text { Середні ча- } \\
\text { шечки }\end{array}$ & $\begin{array}{c}\text { Верхні } \\
\text { та нижні } \\
\text { чашечки }\end{array}$ & $\begin{array}{c}\text { Верхні } \\
\text { та середні } \\
\text { чашечки }\end{array}$ & $\begin{array}{c}\text { верхні } \\
\text { чашечки }\end{array}$ & $\begin{array}{c}\text { нижні } \\
\text { чашечки }\end{array}$ \\
\hline Розмір пухлини (см) & 2,2 & 4 & 3,3 & 4,1 & 2,8 & 3,7 & $\begin{array}{c}\text { 5,2 (зліва) } \\
2,2 \text { (справа) }\end{array}$ & 4,6 & 3,3 & 4,2 \\
\hline рТ стадія & ॥ & II & II & II & II & ॥ & $\begin{array}{l}\text { II (зліва) } \\
\text { ІІ (справа) }\end{array}$ & ॥ & ॥I & ॥ \\
\hline $\mathrm{N}$ стадія & Відсутня & Відсутня & Відсутня & Відсутня & Відсутня & Відсутня & Відсутня & Відсутня & відсутня & відсутня \\
\hline $\begin{array}{l}\text { Ступінь диференціюван- } \\
\text { ня (Gr) }\end{array}$ & 2 & 3 & 2 & 3 & 2 & 2 & $\begin{array}{c}3 \text { (зліва) } \\
1 \text { (справа) }\end{array}$ & 2 & 2 & 2 \\
\hline Лімфоваскулярна інвазія & & Так & & & & & Так & & & \\
\hline
\end{tabular}

Таблиця 3. Функціональні результати резекції нирки при уротеліальному раку високого ризику

\begin{tabular}{|c|c|c|c|c|c|c|c|c|c|c|}
\hline \multirow{2}{*}{ Показник } & \multicolumn{10}{|c|}{ Пацієнт } \\
\hline & 1 & 2 & 3 & 4 & 5 & 6 & 7 & 8 & 9 & 10 \\
\hline Ішемія нирки & & & & Tак & & & & & & \\
\hline \% здорової паренхіми & 64 & 61 & 71 & 66 & 67 & 66 & 71 (зліва) & 71 & 69 & 68 \\
\hline & & & & & & & 84 (справа) & & & \\
\hline $\begin{array}{l}\text { Передопераційна загаль- } \\
\text { на клубочкова фільтра- } \\
\text { ція, мл/хв }\end{array}$ & 71 & 65 & 63 & 64 & 59 & 48 & 85 & 75 & 69 & 59 \\
\hline $\begin{array}{l}\text { Пілсяопераційна загаль- } \\
\text { на клубочкова фільтра- } \\
\text { ція, мл/хв }\end{array}$ & 63 & 60 & 59 & 56 & 55 & 42 & 84 & 65 & 61 & 52 \\
\hline Ад'ювантна хіміотерапія & & & & Так & Так & $\begin{array}{l}\text { Так (гем- } \\
\text { цитабін - } \\
\text { карбопла- } \\
\text { тин) }\end{array}$ & Так & Так & Так & Tak \\
\hline
\end{tabular}

Таблиця 4. Онкологічні результати резекції нирки при уротеліальному раку високого ризику

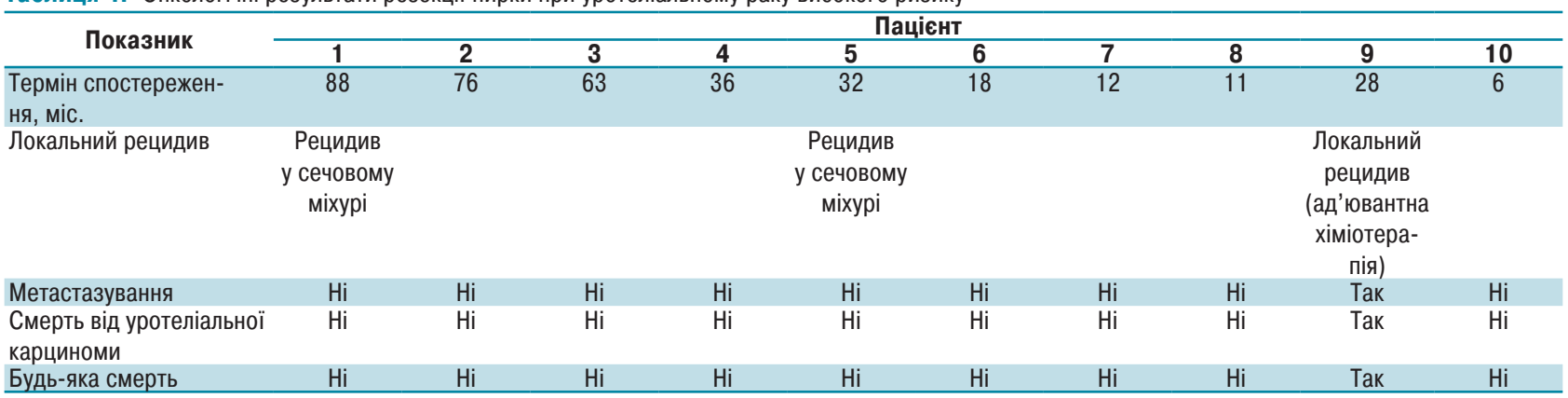


стереження. 3 метою профілактики рецидиву 7 пацієнтам проведено 3 курси ад'ювантної поліхіміотерапії за схемою гемцитабін - цисплатин у стандартних дозуваннях. Відтак у досліджуваній групі лише у 1 (10\%) пацієнта зафіксовано прогресування на фоні лікування та смерть внаслідок метастазування хвороби.

Згідно зі статистичним аналізом за Фішером, ризик локального рецидиву в сечовій системі не залежав від розміру пухлини $(\mathrm{p}=0.932)$ або їі морфологічної будови $(\mathrm{p}=1,0)$.

\section{ОБГОВОРЕННЯ}

Досвід, отриманий під час виконання органозберігаючих оперативних втручань при лікуванні КВСШ, що уражують чашечки нирки, свідчить на користь перспективності використання методу у даної групи пацієнтів. На момент публікації 9 хворих знаходяться під спостереженням клініки, у 2 випадках діагностовано рецидив у сечовому міхурі, що стало причиною ендоскопічного лікування. У подальшому цим пацієнтам проведено внутрішньоміхурову хіміотерапію згідно зі стандартами, та при контрольних обстеженнях дані про рецидив виявлено не було. У 1 випадку відмічено локальний рецидив захворювання, що потребував радикальної нефроуретеректомії та подальшої системної хіміотерапії, що завершилася канцерспецифічною смертю. У жодного пацієнта з групи дослідження не відмічено розвитку хронічної ниркової недостатності в процесі спостереження, що свідчить на користь хороших функціональних результатів обраної методики. Враховуючи задовільні функціональні результати, 7 пацієнтам можна було провести ад’ювантну хіміотерапію з метою покращення онкологічних результатів, що в кінцевому результаті могло вплинути на рівень безрецидивної виживаності. Збереження функції нирки у обраної категорії хворих спрямоване на покращення не тільки загальної, але й онкологічної виживаності. Оперативні втручання та післяопераційний період не супроводжувалися значущими ускладненнями, переважно обмежуючись загостренням пієлонефриту, що був купіруваний на фоні зміни антибактеріальної терапії.

Враховуючи невелику вибірку пацієнтів та рідкісність нозології, у популяції достатньо важко визначити фактори, котрі б достовірно впливали на прогноз та перебіг захворювання. Так, зрозумілим $€$ те, що сучасні системи гістологічної оцінки агресивності уротеліальних КВСШ не дозволяють чітко стратифікувати оптимальну хірургічну тактику для пацієнта. Резекція нирки може слугувати альтернативою ендоскопічному та органовиносному лікуванню при пухлинах чашечко-мискової системи не тільки у пацієнтів, котрі мають прямі показання до збереження нирки у зв'язку з прогресуванням ниркової недостатності та низькими показниками соматичного стану. Усі хворі, дані яких було проаналізовано, характеризувалися задовільним індексом Чарльстона та ECOG-статусом з невираженою супутньою патологією, перебіг якої не погіршився після перенесеного хірургічного лікування.

Загалом варто констатувати загальну безпеку підходу в контексті ризиків поширення пухлинних мас за межі хірургічної зони та невисокий рівень хірургічних ускладнень. Втім, необхідно відзначити, що хірургічна резекція чашечок $є$ технічно складним оперативним втручанням та може бути використана лише у високоспеціалізованих центрах з достатнім хірургічним досвідом оперативних втручань на нирках.

Базуючись на статистичному аналізі, можна припустити, що функціональний потенціал нирки відрізняється у різних хворих, тоді як покращення клубочкової фільтрації на боці ураження прямо не корелювало з відсотком здорової паренхіми. Функціональний потенціал нирки при КВСШ прямо не залежить від відсотка здорової паренхіми та може змінюватися залежно від індивідуальних особливостей організму. Враховуючи принципове значення рівня клубочкової фільтрації в лікуванн нозології, збереження нирки є перспективним та доцільним при збереженні більше 50\% тканини органу та значенні швид- кості клубочкової фільтрації більше ніж 10 мл/хв. У тому числі важливо відмітити ймовірний позитивний вплив відсутності використання ішемії при резекції на кінцевий функціональний результат.

Загалом варто констатувати вкрай малий світовий досвід органозберігаючого лікування при карциномах високого ступеня ризику, що локалізуються в чашечках нирки. У пацієнтів з інвазивними КВСШ у 25-50\% випадків відмічають прогресування з утворенням метастазів, вони потребують системної терапії після радикальної нефроуретеректомії [7]. Проте для цих хворих достатньо характерною є хронічна ниркова недостатність, що фактично унеможливлює повноцінне проведення ефективного ад'ювантного лікування [5]. У цьому контексті на перший план виходить важливість збереження функціонального стану нирок, оскільки системи градації та прогнозування, що існують на сьогодні, не дають чіткої відповіді на поставлені питання та не допомагають визначити групу пацієнтів, що мають підвищений ризик прогресування. Отримані нами результати, хоча й у малої вибірки пацієнтів, втім, зі складною анатомічною локацією, вказують на клінічну ефективність обраного підходу при даній патології у окремо обраних випадках.

\section{вИСновКИ}

Уротеліальний рак верхніх сечових шляхів є відносно рідкісним онкологічним захворюванням, підходи до лікування якого динамічно змінюються. Методи терапії багато в чому базуються на знаннях про уротеліальний рак загалом, котрий здебільшого представлений раком сечового міхура. Відмінність анатомічних та фізіологічних особливостей цих двох нозологій, більш швидкий розвиток та прогресування ниркової недостатності у разі раку верхніх сечових шляхів вимагає перегляду стандартних підходів.

Резекція сегменту верхніх сечових шляхів є перспективним методом хірургічного лікування, що дозволяє зберегти ниркову функцію при ідентичних онкологічних результатах. Збереження функції нирки дозволяє не тільки знизити вірогідність розвитку ниркової недостатності, що позитивно впливає на перебіг супутньої патології, але й дозволяє проводити ад'ювантну хіміотерапію. Резекція нирки у цьому контексті $€$ найбільш технічно складним втручанням, що потребує ретельного відбору та обстеження пацієнтів, проте забезпечує хороші функціональні та онкологічні результати.

Відсутність прямої залежності між відсотком здорової паренхіми та змінами функції нирки в післяопераційний період може мати принципове значення та вказувати на доцільність збереження органа навіть у разі необхідності резекції близько $50 \%$ тканини.

\section{СПИСОК ВИКОРИСТАНОЇ ЛІТЕРАТУРИ}

1. Adibi, M., Youssef, R., Shariat, S. F., Lotan, Y., Wood, C. G., Sagalowsky, A. I., Margulis, V. (2012). Oncological outcomes after radical nephroureterectomy for upper tract urothelial carcinoma: comparison over the three decades. International Journal of Urology, 19(12), 1060-1066. doi: 10.1111/j.1442-2042.2012.03110.x.

2. Go, A. S., Chertow, G. M., Fan, D., \& McCulloch, C. E. (2004). Chronic kidney disease and the risks of death, cardiovascular events, and hospitalization. The New England Journal of Medicine, 351, 1296-1300. doi: 10.1056/NEJMoa041031.

3. Huang, W. C., Levey, A. S., Serio, A. M., Snyder, M., Vickers, A. J., Raj, G. V., Russo, P. (2006). Chronic kidney disease after nephrectomy in patients with renal cortical tumours: a retrospective cohort study. The Lancet Oncology 7, 735-740. doi: $10.1016 / \mathrm{S} 1470-2045(06) 70803-8$.

4. Jeldres, C., Lughezzani, G., Sun, M., Isbarn, H., Shariat, S., Budäus, L., Karakiewicz, P. I. (2010). Segmental ureterectomy can safely be performed in patients with transitional cell carcinoma of the ureter. The Journal of Urology, 183, 1324-1329. doi: 10.1016/j.juro.2009.12.018.

5. Lane, B. R. Smith, A. K., Larson, B. T., Gong, M. C., Campbell, S. C., Raghavan, D., ... Stephenson, A.J. (2010). Chronic kidney disease after nephroureterectomy for upper tract urothelial carcinoma and implications for the administration of perioperative chemotherapy. Cancer, 15, 2967-2973. doi: 10.1002/cncr.25043.

6. Lehmann, J., Suttmann, H., Albers, P., Volkmer, B., Gschwend, J. E., Fechner, G., Stöckle, M. (2009) Surgery for metastatic urothelial carcinoma with curative intent: the German experience (AUO AB 30/05). European Urology, 55(6), 1293-1299. doi: 10.1016/j.eururo.2008.11.039.

7. Margulis, V., Shariat, S. F., Matin, S. F., Kamat, A. M., Zigeuner, R. Kikuchi, E.,... Raman, J. D. (2009). Outcomes of radical nephroureterectomy: a series from the Upper Tract Urothelial Carcinoma Collaboration. Cancer, 115,1224-1233. doi: $10.1002 /$ cncr.24135. 
8. Munoz, J. J., \& Ellison, L. M. (2000). Upper tract urothelial neoplasms: incidence and survival during the last 2 decades. The Journal of Urology, 164, 1523-1525. PMID 11025695.

9. Nuhn, P., Novara G., Seitz, C., Gupta, A., Matsumoto, K., Kassouf, W., ... Bastian, P.J. (2015). Prognostic value of prior history of urothelial carcinoma of the bladder in patients with upper urinary tracturothelial carcinoma: results from a retrospective multicente study. World Journal of Urology, 33(7), 1005-1013. doi: 10.1007/s00345-014-1363-9.

10. Oosterlinck, W., Solsona, E., van der Meijden, A. P., Sylvester, R., Bohle, A., Rintala, E., \& Lobel, B. (2004). EAU guidelines on diagnosis and treatment of upper urinary tract transitional cell carcinoma. European Urology, 46, 147-154. doi: 10.1016/j.eururo.2004.04.011.

11. Porten, S, Siefker-Radtke, A. O., Xiao, L., Margulis, V., Kamat, A. M., Wood, C. G., Matin, S. F. (2014). Neoadjuvant chemotherapy improves survival of patients with upper tract urothelial carcinoma. Cancer, 120(12), 1794-1799. PMID: 24633966

12. Rouprêt, M., \& Colin, P. (2015). Risk-adapted strategy for the kidney-sparing management of upper tract tumours. Nature Reviews Urology, 12(3), 155-166. doi: 10.1038/nrurol.2015.24

13. Rouprêt, M., Colin, P. \& Yates, D. R. (2013). A new proposal to risk stratify urothelial carcinomas of the upper urinary tract (UTUCs) in a predefinitive treatment setting: low-risk versus high-risk UTUCs. European Urology, 66, 181-183. doi: 10.1016/j.eururo.2013.12.007.

14. Xylinas, E., Rink, M., Margulis, V., Clozel, T., Lee, R. K., Comploj, E., Shariat, S. F. (2013). Impact of renal function on eligibility for chemotherapy and survival in patients who have undergone radical nephro-ureterectomy. BJU International, 112(4), 453-461. doi: 10.1111/j.1464-410X.2012.11649.x.

15. Zigeuner, C., Hutterer, G., Chromecki, T., Winkelmayer, I., Rehak, P. \& Zigeuner, R. (2006). pT classification, grade, and vascular invasion as prognostic indicators in urothelial carcinoma of the upper urinary tract. Modern Pathology, 19 272-279. doi: 10.1038/modpathol.3800529.

16. Zigeuner, R., \& Pummer, K. (2008). Urothelial carcinoma of the upper urinary tract: surgical approach and prognostic factors. European Urology, 53, 720-731. doi: 10.1016/j.eururo.2008.01.006.

\section{Резекция почки при уротелиальном раке чашечек высокой степени риска}

М.В. Пикуль, Э.А. Стаховский, О.А. Войленко, А.Э. Стаховский, Ю.В. Витрук, А.А.Кононенко, С.Л. Семко, Б.А. Гречко,

Д.А. Кошель

\section{Национальный институт рака, Киев}

Резюме. Карциномы верхних мочевых путей (КВМП) составляют около $10 \%$ случаев новообразований почек и 5\% среди уротелиальных опухолей. Крайне мало выраженная клиническая картина достаточно часто приводит к выявлению патологии на поздних стадиях. Около 60-80\% случаев на момент установления диагноза характеризуются инвазивным мультифокальным ростом. Радикальная нефроуретерэктомия - стандарт лечения КВМП - приводит к ухудшению функции почек. Потеря функции почек снижает возможность проведения системной химиотерапии и ухудшает показатели выживаемости. Анатомическое размещение уротелиальных образований в чашечках почки считается хирургически сложной локализации. Выполнение органосохраняющего лечения при инвазивных уротелиальных карциномах в этой точке, по данным литературы, лимитировано отдельными клиническими случаями и его отдаленные функциональные и онкологические результаты являются неизученными. Целью работы было определение онкологической и функциональной эффективности выполнения резекции чашечек почки при инвазивных КВМП. Материалы и методы. После проведения ретроспективного анализа медицинской документации 125 пациентов с КВМП, подлежащих хирургическому лечению в отделении пластической и реконструктивной онкоурологии на базе Национального института рака с 2008 по 2020 г., была выделена группа из 10 пациентов с опухолями чашечек почки высокого риска, у которых использовали органосохраняющий подход. Всем выбранным больным проведено комплексное обследование, включавшее компьютерную или магнитнорезонансную томографию, цистоскопию с уретероскопией и биопсией новообразования, цитологическое исследование мочи и динамическую реносцинтиграфию. Местно-распространенный характер роста опухоли был критерием исключения из исследования. Учитывая небольшую выборку пациентов, оценка клинических результатов группы проводилась на основе теста Фишера. Результаты. Период наблюдения за пациентами колебался в пределах от 3 до 107 мес и в среднем составил 35 мес. Средний возраст больных 59 лет. У 4 пациентов на дооперационном этапе получены положительные результаты цитологического исследования мочи. Размер опухоли колебался в пределах от 2,3 до 6,6 см (в среднем 4,3 см). Среднее время оперативного вмешательства составило 238土36 мин (колебалось в пределах 186-269). Все оперативные вмешательства выполняли без использования центральной ишемии. Интраоперационно после мобилизации почки с целью уточнения границ резекции проводилось рассечение почечной лоханки, через которую заводился гибкий уретеропиелоскоп и под визуальным контролем проводилось окончательное планирование линии резекции. Кровопотеря в среднем составляла 400 мл (колебалась в пределах 150-850 мл). Продолжительность пребывания в стационаре в послеоперационный период составила $6,3 \pm 1,8$ сут (колебалась в пределах 3-9 дней). У 4 из 9 пациентов в послеоперационный период отмечено осложнения с медианным показателем по шкале Clavien - Dindo 1,5 (колебался в пределах 1-2). У всех пациентов по данным патоморфологического исследования была верифицирована уротелиальная карцинома, которая у 1 больного была высокодифференцированной, у 5 - умереннои у 3 - низкодифференцированной. Ни у одного больного не было выявлено клинических данных о раке in situ. Функция пораженной почки через 1 год после оперативного вмешательства в среднем составляла 17 мл/мин. При анализе с помощью точного теста Фишера не выявлено статистически достоверной зависимости между остаточной паренхимой и показателями унилатеральной клубочковой фильтрации $(p=0,173)$ или уровнем послеоперационного креатинина $(\mathrm{p}=0,163)$. В одном (10\%) случае отмечен локальный рецидив заболевания, потребовавший последующей радикальной нефроуретерэктомии и системной терапии в связи с прогрессированием и развитием метастазов. С целью профилактики рецидива 7 пациентам были проведены 3 курса адъювантной полихимиотерапии по схеме гемцитабин - цисплатин в стандартных дозировках. Поэтому в исследуемой группе только у 1 (10\%) пациента отмечено прогрессирование на фоне лечения, он умер в результате метастазирования болезни. Согласно статистическому анализу по Фишеру, риск локального рецидива в мочевой системе не зависел от размера опухоли $(\mathrm{p}=0,932)$ или ее морфологического строения $(\mathrm{p}=1,0)$. Выводы. Резекция сегмента верхних мочевых путей является перспективным методом хирургического лечения, что позволяет сохранить функцию почек при идентичных онкологических результатах. Сохранение функции почки позволяет не только снизить вероятность развития почечной недостаточности, положительно влияет на течение сопутствующей патологии, но и оставляет возможность проведения адъювантной химиотерапии.

Ключевые слова: уротелиальный рак; карцинома верхних мочевыводящих путей; радикальная нефроуретерэктомия; малоинвазивные органосохраняющие оперативные вмешательства; клубочковая фильтрация; уротелиальные образования чашечек почки; эндоскопическая верификация диагноза; метастатическая болезнь.

\section{Partial nephrectomy in high-risk urothelial cancer} of the calyx

M. Pikul, E. Stakhovsky, O. Voylenko, O. Stakhovsky, Iu. Vitruk, O. Kononenko, S. Semko, B. Hrechko, D. Koshel

National Cancer Institute, Kyiv

Introduction. Upper urinary tract cancer (UTUC) amounts approximately $10 \%$ of all cases among kidney lesions and $5 \%$ of all urothelial cancers. Limited clinical sympotms often lead to late stage diagnosis. Around $60-80 \%$ of all cases are invasive and multifocal at primary examination. Radical nephroureteretomy remains the standart of care although it leads to kidney function decrease. Renal function loss often limits the use of systemic therapy in this patients thus decreasing oncological outcomes. Anatomical location of urothelial carcinomas in kidney calyx is known to be the most surgically complex. Organ-sparing treatment in this area among patients with high-risk urothelial carcinomas of the upper urinary tract is limited to clinical cases or small retrospective studies in the literature. Functional and oncological outcomes of such approach 


\section{Оригінальні статті / Original Articles}

remain unclear. The aim of our study was to estimate oncological and functional outcomes of partial nephrectomy in patients with high-risk urothelial carcinomas of the renal calyx. Materials and methods. Retrospective data base analysis of 125 patients with UTUC that underwent surgical treatment in National Cancer Institute. The group of 10 patients with high-risk calyx tumors which underwent organ-sparing approach was selected for further analysis. All patients underwent complex examination that included CT or MRI, cystoscopy with uretheroscopic biopsy, urine cytology and dynamic scintigraphy. Locally advanced cases were excluded at basic data evaluation. Statistical analysis was done using exact Fischer's test taking to account low group volume. Results. Observational period varied from 3 to 107 months with an average of 35 . Average age -59 years. 4 patients had positive urine cytology. Tumor size ranged from 2,3 to $6,6 \mathrm{~cm}$ (average $4,3 \mathrm{~cm}$ ). Average surgical time $-238 \pm 36 \mathrm{~min}(186-269)$. Average blood loss $-400 \mathrm{ml}$ $(150-850 \mathrm{ml})$. Duration of postoperative stay was $6,3 \pm 1,8$ days (3-9 days). Four of 9 patients had Clavien - Dindo complications rate $1-2$. Affected kidney function one year after surgery estimated $17 \mathrm{ml} / \mathrm{min}$ in average. Exact Fischer's test didn't reveal any dependence between remaining functioning parenchyma volume and unilateral kidney function $(p=0,173)$ or postoperative creatinine level $(p=0,163) .1 / 10(10 \%)$ patient died due disease progression during observational period. $2 / 10(20 \%)$ patient had bladder recurrence that was succesfully managed endoscopically. $7 / 10$ cases underwent full dose platinum-based chemotherapy with no dose reduction. Exact Fischer's test didn't reveal any dependence between recurrence rate and tumor size $(p=0,932)$ or pathologic stage $(p=1,0)$. Conclusion. Partial nephrectomy is an option for management of high-risk upper urinary tract cancer. It provides functional benefit thus creating a chance for effective systemic therapy.

Key words: Urothelial cancer; upper urinary tract cancer; radical nephroureterectomy, minimally invasive organ-sparing surgery; glomerulal filtration; urothelial lesions of kidney calyx; endoscopic biopsy; metastatic disease.

Адреса:
Пікуль Максим Валентинович
03022, Київ, вул. Ломоносова, 33/43
$\begin{aligned} & \text { Національний інститут раку } \\ & \text { E-mail: urogenetics@gmail.com } \\ & \text { Correspondence: } \\ & \text { Pikul Maksym } \\ & \text { 33/43 Lomonosova Str., Kyiv 03022 } \\ & \text { National Cancer Institute } \\ & \text { E-mail: urogenetics@gmail.com }\end{aligned}$

